doi: 10.18484/2305-0047.2019.3.276

$$
\begin{gathered}
\text { V. SIHOTSKY }{ }^{1,2}, \text { I. KOPOLOVETS }^{1,3}, \text { M. KUBIKOVA }^{1,2} \text {, } \\
\text { P. STEFANIC }{ }^{1,2}, \text { V. KATUCH }^{2}
\end{gathered}
$$

\title{
RESULTS OF SURGICAL TREATMENT OF PATIENTS WITH AORTOILIAC ATHEROSCLEROSIS
}

\author{
Eastern Slovak Institute of Cardiovascular Diseases ${ }^{1}$, \\ Pavol Jozef Safarik University ${ }^{2}$, Kosice, \\ the Slovak Republic \\ Uzhhorod National University ${ }^{3}$, Uzhhorod, \\ Ukraine
}

Цель. Изучить результаты хирургического лечения пациентов с аорто-подвздошной патологией в раннем послеоперационном периоде.

Материал и методы. В исследование включено 103 пациента с аортальной патологией, которые были направлены в клинику сосудистой хирургии с 2015 по 2017 год. Прооперировано 53 пациента с аорто-подвздошным атеросклерозом и 50 пациентов с аневризмой абдоминальной аорты. Показанием к операции были перемежающаяся хромота, критическая ишемия конечности или острый тромбоз аорты у пациентов с аорто-подвздошным атеросклерозом. Показанием к операции у пациентов с аневризмой абдоминальной аорты была аневризма более 5,5 см в поперечном диаметре или разрыв аневризмы. Ранние результаты хирургического лечения пациентов оценивали по частоте послеоперационных осложнений и летальных исходов.

Результаты. Из 53 пациентов с аорто-подвздошным атеросклерозом 49 (92,5\%) пациентов были прооперированы в плановом порядке и 4 (7,5\%) пациента были прооперированы ургентно. Выполнено 52 $(98,2 \%)$ аорто-бифеморальных шунтирования и один $(1,8 \%)$ аорто-феморальный (односторонний) шунт. Три осложнения $(6,1 \%)$ наблюдались у пациентов, которые были прооперированы в плановом порядке, и одно осложнение $(25 \%)$ у пациента, которого оперировали в ургентном порядке. Среди ургентных пациентов смертность составила 25\%, среди плановых - 2,0\%. Прооперированы 28 пациентов с бессимптомной аневризмой абдоминальной аорты и 22 пациента с разрывом аневризмы абдоминальной аорты. Смертность после плановой операции составила $3,6 \%$. У пациентов с разрывом аневризмы абдоминальной аорты смертность составила 40,9\%.

Заключение. Хорошие и удовлетворительные результаты планового хирургического лечения симптоматического аорто-подвздошного атеросклероза в раннем послеоперационном периоде составили $98 \%$, асимптоматической аневризмы аорты - 96,4\%. Смертность после ургентной операции при разрыве аневризмы составила 40,9\%. Хирургическое лечение аневризмы аорты показано у пациентов с низким и средним хирургическим риском.

Ключевые слова: атеросклероз, аневризма аорты, критическая ишемия конечности, аорто-подвздошная реконструкция

Objective. To investigate the results of surgical treatment of patients with aortoiliac pathology in the early postoperative period.

Methods. In the study 103 patients with aortoiliac pathology were included, who were referred to the Clinic of Vascular Surgery from 2015 to 2017 years. 53 patients were operated on because of aortoiliac atherosclerosis and 50 patients - because of abdominal aortic aneurysm. The indications for surgery were limiting claudication, critical limb ischemia or acute thrombosis of the aorta in patients with aortoiliac atherosclerosis. The indication for surgery in patients with abdominal aortic aneurysm was the aneurysm over $5.5 \mathrm{~cm}$ in the transverse diameter or the ruptured aneurysm. Early results of patients' surgical treatment were assessed by the frequency of postoperative complications and deaths.

Results. $49(92.5 \%)$ out of 53 patients with aortoiliac atherosclerosis were operated on as planned and $4(7.5 \%)$ patients were operated on urgently. $52(98.2 \%)$ aortobifemoral bypasses and one (1.8\%) aortofemoral (unilateral) bypass were performed. Three complications $(6.1 \%)$ occurred postoperatively in patients operated on according to plan and one complication $(25 \%)$ - in patients operated urgently. The mortality rate was $25 \%$ in urgent patients and $2.0 \%$ in planned patients. 28 patients with asymptomatic abdominal aortic aneurysm and 22 with the ruptured abdominal aortic aneurysm were operated on. The mortality in the planned patients was $3.6 \%$. $40.9 \%$ mortality rate was registered in the ruptured abdominal aortic aneurysm patients.

Conclusions. Early good and satisfactory results of the routine surgical treatment of symptomatic aortoiliac atherosclerosis in the early postoperative period accounted $98 \%$, asymptomatic aortic aneurysm $-96.4 \%$. Mortality after urgent surgery with aneurysm rupture made up $40.9 \%$. Surgical treatment of aortic aneurysm is indicated in patients with low and moderate surgical risk. 
Keywords: atherosclerosis, aortic aneurysms, critical limb ischemia, aortoiliac reconstructions

Novosti Khirurgii. 2019 May-Jun; Vol 27 (3): 276-283

The articles published under CC BY NC-ND license

Results of Surgical Treatment of Patients with Aortoiliac Atherosclerosis

V. Sihotsky, I. Kopolovets, M. Kubikova, P. Stefanic, V. Katuch

Научная новизна статьи

Установлено, что смертность плановой открытой аортальной операции при абдоминальных аневризмах составляет около 3,6\%, смертность при разрыве аневризмы достигает 40,9\%.

\section{What this paper adds}

It has been established that the mortality rate of the planned open aortic surgery for abdominal aneurysms is about $3.6 \%$, the mortality rate after the rupture of the aneurysm reaches $40.9 \%$.

\section{Introduction}

Aortoiliac reconstruction represents the possibilities of surgical treatment of atherosclerosis, both obliterating disease and aortoiliac aneurysm. The first aortoiliac reconstruction was performed by Wylie in the USA, who in 1951 did aortic bifurcation thrombendarterectomy in atherosclerotic obliteration [1]. The first reconstruction of an aortic aneurysm was carried out by Dubost in Paris in 1951. He restored continuity after resection of the aortic aneurysm rupture using a preserved human aortic graft [1]. But the further development of the aortoiliac reconstruction was impossible due to the lack of aortic allografts, which represented the only possibility of restoring aortic continuity. The golden era of aortoiliac reconstructions began with the invention of aortic-bifemoral shunts [2]. The introduction of endovascular treatment of aortic pathologies was the second important factor that changed the possibilities of treatment. At the beginning of our millennium, the widespread development of interventional procedures changed the approach to the treatment of aortoiliac pathology. Aortoiliac reconstruction is performed as a surgical treatment of aortoiliac atherosclerosis, which cannot be treated endovascularly, mainly to TASC D patients, according to the TASC (TransAtlantic Inter-Society Consensus) classification [3]. Surgical treatment of abdominal aortic aneurysm (AAA) is indicated for asymptomatic treatment in patients with aneurysms with the diameter of more than $5.5 \mathrm{~cm}$ in cross section or in the rupture of AAA [4].

According to the updated AAA treatment guidelines, according to the European Society of Vascular Surgery (ESVS) from 2019, surgical treatment is an option for patients with a life expectancy of more than 10-15 years. Routine AAA surgery is not recommended for patients with terminal cancer, patients with severe heart failure and a life expectancy of less than $2-3$ years. $[5,6]$.

Objective. To investigate the results of surgical treatment of patients with aortoiliac pathology in the early postoperative period.

\section{Methods}

The study was conducted in the Clinic of Vascular Surgery of Eastern Slovak Institute of Cardiovascular Diseases, Kosice, Slovakia. A retrospective study included 103 patients with aortoiliac pathology who were referred to the department from January 2015 to December 2017. 53 patients with aortoiliac atherosclerosis and 50 patients with AAA were operated on. Indications for surgery were intermittent claudication, critical limb ischemia or acute aortic thrombosis in patients with aortoiliac atherosclerosis. The diagnosis of aortoiliac atherosclerosis was based on CT angiography or angiography. Indications for surgery were exposed to patients with AAA more than $5.5 \mathrm{~cm}$ in transverse diameter and all patients with the aneurysm rupture. The diagnosis of AAA was established using ultrasound and CT angiography.

\section{Results}

Aortoiliac atherosclerosis. 49 (92.5\%) out of 53 patients with aortoiliac atherosclerosis were operated on in the planned manner and 4 (7.5\%) patients were operated urgently (Table 1).

$52(98.2 \%)$ aortic-bifemoral bypass operations and one (1.8\%) aortic-femoral (one-sided) shunting to the right due to the superimposed sigmostomy were performed. Aortic-bifemoral bypass was performed using a Dacron prosthesis, the proximal anastomosis was standardized by the side-to-end principle. Distal anastomoses were placed in the common femoral artery with the continuation of the anastomosis to the end-to-side deep femoral artery.

Additional interventions of aortic-bifemoral bypass were: AAA resection with the end-to-end anastomosis in 2 patients, aortic thrombectomy in 8 patients due to subrenal aortic thrombosis, and in one patient the lower mesenteric artery was re-implanted to prevent left ischemic ischemia (Table 2).

There were four complications requiring reoperation after aortic reconstruction: three complications $(6.1 \%)$ occurred in patients who were operated on in a planned manner (bleeding in one patient and prosthetic thrombosis in two 
Aortoiliac reconstructions carried out in the department for 2015-2017

\begin{tabular}{lcc}
\hline Diagnosis & Number & $\%$ \\
\hline Aortoiliac atherosclerosis - planned & 49 & $47.6 \%$ \\
Aortoiliac atherosclerosis - urgent & 4 & $3.9 \%$ \\
Abdominal aortic aneurism (planned) & 28 & $27.2 \%$ \\
Abdominal aortic aneurysm rupture & 22 & $21.4 \%$ \\
All patients & 103 & $100 \%$ \\
\hline
\end{tabular}

Table 2

Additional interventions for aortobifemoral bypass. Aneurysm of the abdominal aorta

\begin{tabular}{lcc}
\hline \multicolumn{1}{c}{ Additional interventions } & Number & $\%$ \\
\hline Additional interventions in aortic-bifemoral bypass & 53 & $100 \%$ \\
Abdominal aortic aneurysm resection and end-to-end anastomosis & 2 & $3.8 \%$ \\
Subrenal aortic thrombectomy & 8 & $15.1 \%$ \\
Reimplantation of the inferior mesenteric artery & 1 & $1.8 \%$ \\
Planned operations & 49 & $92.5 \%$ \\
Urgent operations & 4 & $7.5 \%$ \\
\hline
\end{tabular}

Table 3

Complications requiring surgery

\begin{tabular}{lccc}
\hline & Complications & Number & $\%$ \\
\hline & Bleeding & 1 & $2 \%$ \\
Planned surgeries & Thrombosis of limb arteries & 2 & $4.1 \%$ \\
& & 3 & $6.1 \%$ \\
Urgent surgeries & Shunt thrombosis - acute & 1 & $25 \%$ \\
Total & & 1 & $25 \%$ \\
\hline
\end{tabular}

patients); one complication (25\%) requiring surgical intervention in a patient (prosthetic thrombosis), which was operated on urgently (Table 3 )

One patient died (25\%) of all urgent patients in the postoperative period; and one patient died operated on in a planned manner (2.0\%).

Aneurysm of the abdominal aorta. 28 surgical interventions for asymptomatic AAA were performed. Aortic shunting was performed in 15 patients using the dacron prosthesis when the iliac arteries were not involved in the aneurysm process. In 13 cases, aorticbifemoral bypass was performed, when the common iliac arteries were expanded by more than $2.5 \mathrm{~cm}$. In cases of aortic-bifemoral bypass, the proximal anastomosis was done end-to-end, and the distal end-to-side. In the case of aorto-aortic prosthesis, the proximal and distal anastomoses were performed end-to-end. Aortic-bifemoral bypass was performed using the dacron prosthesis, the distal anastomoses were sutured into the common femoral artery with the continuation of the anastomosis to the deep femoral artery. The lower mesenteric artery was reimplanted into the prosthesis in four patients (Fig. 1).

Reimplantation was performed to prevent ischemia of the left colon, when both internal iliac arteries were transfected and ligated during the surgery. One patient died after the planned surgery; the mortality rate was $3.6 \%$. (Table 4 ).
22 patients were operated on due to rupture of AAA. Eleven aorto-aortic reconstructions, 9 aortic-bifemoral reconstructions, and 2 explorative laparotomies were performed when patients died during the surgical resuscitation. In one patient with suprarenal AAA, it became necessary to reimplant both renal arteries. Eight patients (36\%) needed reoperations: three due to acute limb ischemia, two due to postoperative bleeding, one due to perforation of peptic ulcer, one due to acute coronary syndrome and one due to infection after laparotomy (Table 5). Nine patients (40.9\%) died in the postoperative period after urgent surgery.

Fig. Reimplantation of the inferior mesenteric artery.

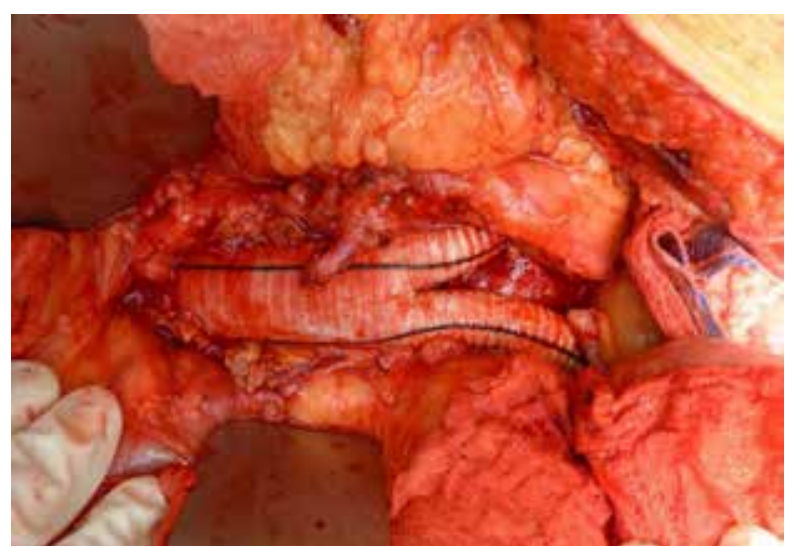


Surgical interventions and complications of asymptomatic abdominal aortic aneurysm

\begin{tabular}{llcc}
\hline & \multicolumn{1}{c}{ Aortic reconstruction } & Number & $\%$ \\
\hline & Aorto-aortic prosthesis & 15 & $54 \%$ \\
& Aortic-bifemoral bypass & 13 & $46 \%$ \\
& Repeated implantation of the inferior mesenteric artery & 4 & $14.2 \%$ \\
Total & & 28 & $100 \%$ \\
& Complications requiring reoperation & 2 & $7.1 \%$ \\
& Bleeding & 1 & $3.6 \%$ \\
& Complications in the groin area & 1 & $3.6 \%$ \\
Total complications & Infection & 4 & $14.2 \%$ \\
Mortality & & 1 & $3.6 \%$ \\
\hline
\end{tabular}

Table 5

Surgical interventions and complications in rupture of the abdominal aortic aneurysm

\begin{tabular}{llcc}
\hline & \multicolumn{1}{c}{ Aortic reconstructions } & 22 & $100 \%$ \\
\hline & Aorto-aortic prosthesis & 11 & $50 \%$ \\
& Aortic-bifemoral bypass & 9 & $41 \%$ \\
& Expiratory laparotomy & 2 & $9 \%$ \\
& Repeated implantation of the renal arteries & 1 & $4.5 \%$ \\
Mortality & & 9 & $40.9 \%$ \\
\hline
\end{tabular}

\section{Discussions}

Aortoiliac reconstructions are performed mainly in atherosclerosis or aneurysm of the aorta and aortoiliac segment. Surgeries are indicated for patients with TASC C or TASC D lesions according to the TASC classification [3]. Aortic-bifemoral bypass is the "gold standard" for the treatment of symptomatic aortoiliac atherosclerosis. There are two possible access to the abdominal aorta: transperitoneal and retroperitoneal, both acceptable and have similar results [1]. Aortic reconstructions are performed mainly with the prosthesis "Dacron". It is preferable that the proximal aorta anastomosis is designed side-to-end, which is technically not so difficult, and also allows for blood flow to the lumbar and pelvic arteries and, therefore, prevents pelvic ischemia [2]. The end-to-end anastomosis is appropriate in cases of AAA or in the case of very common aortic atherosclerosis, when only a small portion of the subrenal aorta is soft [7]. In such situations, the proximal anastomosis is performed on the cross-clamping aorta. In our group of patients, we performed the end-to-end anastomosis in only two (3.8\%) patients who had AAA. In one patient, we reimplanted the inferior mesenteric artery to prevent ischemia of the left colon. The distal anastomosis should be placed on the common femoral artery with the continuation of the anastomosis on the deep femoral artery to prevent the stenosis of the latter in future. Stenosis of the deep femoral artery can lead to limb thrombosis. Profundoplasty plays an important role in maintaining the long-term patency of aortic-bifemoral bypass operations [8].
Aortic-bifemoral bypass is a safe procedure with a very low mortality rate, up to $2 \%$ and a 10 -year patency of $75-85 \%$ [7]. In the presented patients, the complication rate in planned cases was $6.1 \%$, mortality - $2.0 \%$. The level of complications and mortality in urgent patients were higher: the complication rate was $25 \%$ and the mortality rate was $25 \%$ among urgent patients. One patient had the prosthesis thrombosis and one patient died in the postoperative period. Thus, it is important to carry out surgical interventions in patients at the stage of a stable course of the disease and to prevent acute occlusion in which there is a high mortality rate of up to $22 \%$ [8]. About $60 \%$ of patients with aortoiliac atherosclerosis also have peripheral artery disease [9]. In $80 \%$ of patients with aortoiliac and femoral atherosclerosis, the symptoms of ischemia are reduced after aortic-bifemoral bypass surgery, and only $20 \%$ of them require reconstruction of the femoral-popliteal arterial segment after aorticbifemoral bypass [5]. Taking into consideration these excellent long-term indices of patency, aorticbifemoral bypass is currently considered the method of choice for revascularization [2].

Another possibility of aortoiliac reconstructions is aortic endarterectomy. Despite this procedure was the first aortoiliac reconstruction, it is not commonly used today. The only advantage of endarterectomy compared with aorto-bifemoral bypass is the absence of prosthetic material, but the endarterectomy has been replaced by bypass operations [6].

Another possibility to manage aortoiliac atherosclerosis is to perform revascularization of 
one iliac artery, either endovascularly or surgically, and then apply an extraanatomical femoro-femoral bypass. Cross-shunting has a lower long-term patency compared with aortic-bifemoral bypass, but does not require laparotomy, so it is intended for polymorbid patients who are not suitable for aortic surgery. The five-year patency of femoro-femoral bypass is about 70\% [9]. But in patients with low and moderate surgical risk, we prefer aortic-bifemoral bypass.

Aneurysms of the abdominal aorta are indications for surgeries in cases where the transverse diameter exceeds $55 \mathrm{~mm}$, when aneurysmal expansion of more than $10 \mathrm{~mm}$ occurs in one year or in case of a rupture [10]. The diagnosis of AAA is based on CT angiography. CT angiography accurately determines the proximal and distal part of AAA, more accurately depicts the iliac arteries and provides important information for the operation planning. This is especially true for modern multi-detector spiral CT with thin sections in the place of interest [6]. Ultrasound is suitable as a screening method, but not as a final diagnostic method in patients with AAA for the planned surgery. However, ultrasound is the key method in unstable AAA rupture patients, which should be used immediately, since CT angiography can lead to delay, intra-abdominal rupture and patient's death [4].

Both approaches of surgical access (transperitoneal and retroperitoneal) can be used during aortic surgery. The choice of surgical access should be determined by the preference of the surgeon and his qualifications [11]. If the aortic aneurysm does not extend to the iliac arteries, end-to-end aorto-aortic prosthesis is performed. In cases of aneurysm of the iliac arteries, aortoiliac or aorto-bifemoral bypass surgery should be performed. The indication for the reconstruction of ileal aneurysm is its diameter of more than 2.5 $\mathrm{cm}$ with concomitant aortic surgery or $3.5 \mathrm{~cm}$ with an isolated reconstruction of the iliac aneurysm. $[1,12]$. Aortoiliac reconstruction is preferred for comorbidities, due to the absence of inguinal incisions. We have good experience of aorticbifemoral bypass in cases of concomitant aortic and iliac aneurysms. Anastomosis in the common femoral artery is not as technically complex as the end-to-end anastomosis in the iliac arteries in the pelvic region, especially in obese men or when aneurysm ruptures. Early mortality after open surgery on aneurysms ranges from $5 \%$ to $8 \%$ [6]. In the presented material, the mortality after planned surgery of aortic aneurysm was $3.6 \%$. Perioperative complications were observed in $14.6 \%$ of patients who were operated on as planned patients.

Recently, a higher increase in endovascular interventions has been registered, resulting in the fact that up to $60 \%$ of planned AAA cases in the USA are being treated with endovascular methods and the open surgical method is reserved for patients with anatomy that is not suitable for EVAR (EndoVascular Aneurysm Repair) [13]. But recent results from randomized controlled studies of EVAR-1 and EVAR-2, after 15 years, have shown that EVAR does not exceed open reconstruction. EVAR has a better early survival rate, but inferior in late survival compared with open operations [5]. EVAR also has a higher rate of reintervention than open surgery. In general, the frequency of repeated interventions with aneurysm was higher in the EVAR group than in the group of open operations: 4.1 and 1.7 per 100 person-years, respectively ( $p$ $<0.001)$, with repeated interventions occurring during the observation [14].

Open AAA operations are indicated for patients with low and moderate surgical risk, and EVAR should be considered in patients with high surgical risk or in patients after multiple abdominal surgeries [6]. Results obtained for over 15 years of observation suggest that EVAR does not prolong life in patients unsuitable for open surgery [14].

Mortality in the reconstruction of AAA rupture is up to $50.8 \%$. Aortic rupture leads to a combination of reperfusion injuries, hemorrhagic shock, lower trunk ischemia and multiorgan failure [11]. In the examined group of patients, the mortality after urgent surgery for the aneurysm rupture was $40.9 \%$.

The only randomized study that assessed death and severe complications of AAA rupture was the Dutch multicenter randomized study (AJAX). AJAX results show that death and severe complications occur in $21 \%$ of patients after EVAR and in $25 \%$ after open repair of the AAA rupture, as is evident, there is no significant difference [15]. In patients with rupture of the abdominal aortic aneurysm, EVAR may be useful in case of appropriate anatomy for endovascular treatment.

\section{Conclusions}

Good and satisfactory results of planned surgical treatment of symptomatic aortoiliac atherosclerosis in the early postoperative period amounted up to $98 \%$, asymptomatic aortic aneurysm - $96.4 \%$. Mortality after urgent surgery with the aneurysm rupture was $40.9 \%$. Surgical treatment of aortic aneurysm is indicated in patients with low and moderate surgical risk.

\section{Funding}

The work was carried out in accordance with the scientific plans of the Clinic of Vascular Surgery 
of Eastern Slovak Institute of Cardiovascular Diseases, Kosice, the Slovak Republic.

The authors did not receive any financial support from manufacturers of medical products.

\section{Conflict of interest}

The authors declare that they have no conflict of interest.

\section{Ethical aspects Ethics Committee approval}

The research is approved by the Ethics Committee of Eastern Slovak Institute of Cardiovascular Diseases, Kosice, the Slovak Republic.

\section{ЛИТЕРАТУРА}

1. Menard MT. Aortoiliac Disease: Direct Aortoiliac Reconstruction. In: Cronenwett JL, Johnston KW. Rutherford's Vascular Surgery. 8h $^{\text {th }}$ ed. Philadelphia: Elsevier Saunders; 2014. p. 1701-21. https://www. uk.elsevierhealth.com/rutherfords-vascular-surgery-2volume-set-9781455753048.html

2. Jaquinandi V, Picquet J, Saumet JL, Benharash P, Leftheriotis G, Abraham P. Functional assessment at the buttock level of the effect of aortobifemoral bypass surgery. Ann Surg. 2008 May;247(5):869-76. doi: 10.1097/SLA.0b013e31816bcd75

3. Norgren L, Hiatt WR, Dormandy JA, Nehler MR, Harris KA, Fowkes FG, Rutherford RB. Intersociety consensus for the management of peripheral arterial disease (TASC II). J Vasc Surg. 2007 Jan;45(Is 1 Suppl):S5-S67. doi: https://doi.org/10.1016/j. jvs.2006.12.037

4. Moll FL, Powell JT, Fraedrich G, Verzini F, Haulon S, Waltham M, van Herwaarden JA, Holt PJ, van Keulen JW, Rantner B, Schlösser FJ, Setacci F, Ricco JB. Management of abdominal aortic aneurysms clinical practice guidelines of the European society for vascular surgery. Eur J Vasc Endovasc Surg. 2011 Jan;41(Suppl 1):S1-S58. doi: 10.1016/j.ejvs.2010.09.011 5. Patel R, Sweeting MJ, Powell JT, Greenhalgh RM. Endovascular versus open repair of abdominal aortic aneurysm in 15-years'follow-up of the UK endovascular aneurysm repair trial 1 (EVAR trial 1): a randomised controlled trial. Lancet. 2016 Nov 12;388(10058):236674. doi: 10.1016/S0140-6736(16)31135-7

6. Wanhainen A, Verzini F, Van Herzeele I, Allaire E, Bown M, Cohnert T, Dick F, van Herwaarden J, Karkos C, Koelemay M, Kölbel T, Loftus I, Mani K, Melissano G, Powell J, Szeberin Z, Esvs Guidelines Committee, de Borst GJ, Chakfe N, Debus S, Hinchliffe R, Kakkos S, Koncar I, Kolh P, Lindholt JS, de Vega M, Vermassen F, Document Reviewers, Björck M, Cheng S, Dalman R, Davidovic L, Donas K, Earnshaw $\mathrm{J}$, Eckstein HH, Golledge J, Haulon S, Mastracci T, Naylor R, Ricco JB, Verhagen H. Editor's Choice European Society for Vascular Surgery (ESVS) 2019 Clinical Practice Guidelines on the Management of Abdominal Aorto-iliac Artery Aneurysms. Eur J Vasc Endovasc Surg. 2019 Jan;57(1):8-93. doi: 10.1016/j. ejvs.2018.09.020
7. Burke CR, Henke PK, Hernandez R, Rectenwald JE, Krishnamurthy V, Englesbe MJ, Kubus JJ, Escobar GA, Upchurch GR Jr, Eliason JL. A contemporary comparison of aortofemoral bypass and aortoiliac stenting in the treatment of aortoiliac occlusive disease. Ann Vasc Surg. 2010 Jan;24(1):4-13. doi: 10.1016/j. avsg.2009.09.005

8. Creager MA, Kaufman JA, Conte MS. Clinical practice. Acute limb ischemia. N Engl J Med. 2012 Jun 7;366(23):2198-206. doi: 10.1056/NEJMcp1006054 9. Huded CP, Goodney PP, Powell RJ, Nolan BW, Rzucidlo EM, Simone ST, Walsh DB, Stone DH. The impact of adjunctive iliac stenting on femoral-femoral bypass in contemporary practice. J Vasc Surg. 2012 Mar;55(3):739-45; discussion 744-5. doi: 10.1016/j. jvs.2011.10.036

10. Becquemin JP, Pillet JC, Lescalie F, Sapoval M, Goueffic Y, Lermusiaux P, Steinmetz E, Marzelle J. A randomized controlled trial of endovascular aneurysm repair versus open surgery for abdominal aortic aneurysms in low- to moderate-risk patients. $J$ Vasc Surg. 2011 May;53(5):1167-73.e1. doi: 10.1016/j. jvs.2010.10.124

11. Patel VI, Lancaster RT, Conrad MF, Lamuraglia GM, Kwolek CJ, Brewster DC, Cambria RP. Comparable mortality with open repair of complex and infrarenal aortic aneurysm. J Vasc Surg. 2011 Oct;54(4):952-59. doi: 10.1016/j.jvs.2011.03.231

12. Williams CR, Brooke BS. Effectiveness of open versus endovascular abdominal aortic aneurysm repair in population settings: A systematic review of statewide databases. Surgery. 2017 Oct;162(4):707-20. doi: 10.1016/j.surg.2017.01.014

13. Albuquerque FC Jr, Tonnessen BH, Noll RE Jr, Cires G, Kim JK, Sternbergh WC 3rd. Paradigm shifts in the treatment of abdominal aortic aneurysm: trends in 721 patients between 1996 and 2008. J Vasc Surg. 2010 Jun;51(6):1348-52; discussion 1352-53. doi: 10.1016/j. jvs.2010.01.078

14. Patel R, Powell JT, Sweeting MJ, Epstein DM, Barrett JK, Greenhalgh RM. The UK EndoVascular Aneurysm Repair (EVAR) randomised controlled trials: long-term follow-up and cost-effectiveness analysis. Health Technol Assess. 2018 Jan;22(5):1-132. doi: $10.3310 /$ hta22050

15. Kapma MR, Dijksman LM, Reimerink JJ, de Groof AJ, Zeebregts CJ, Wisselink W, Balm R, Dijkgraaf MG, Vahl AC. Cost-effectiveness and costutility of endovascular versus open repair of ruptured abdominal aortic aneurysm in the Amsterdam Acute Aneurysm Trial. Br J Surg. 2014 Feb;101(3):208-15. doi: $10.1002 /$ bjs. 9356

\section{REFERENCES}

1. Menard MT. Aortoiliac Disease: Direct Aortoiliac Reconstruction. In: Cronenwett JL, Johnston KW. Rutherford's Vascular Surgery. 8th $^{\text {th }}$ ed. Philadelphia: Elsevier Saunders; 2014. p. 1701-21. https://www. uk.elsevierhealth.com/rutherfords-vascular-surgery-2volume-set-9781455753048.html

2. Jaquinandi V, Picquet J, Saumet JL, Benharash P, Leftheriotis G, Abraham P. Functional assessment at the buttock level of the effect of aortobifemoral bypass surgery. Ann Surg. 2008 May;247(5):869-76. doi: 10.1097/SLA.0b013e31816bcd75

3. Norgren L, Hiatt WR, Dormandy JA, Nehler MR, Harris KA, Fowkes FG, Rutherford RB. Inter- 
society consensus for the management of peripheral arterial disease (TASC II). J Vasc Surg. 2007 Jan;45(Is 1 Suppl):S5-S67. doi: https://doi.org/10.1016/j. jvs.2006.12.037

4. Moll FL, Powell JT, Fraedrich G, Verzini F, Haulon S, Waltham M, van Herwaarden JA, Holt PJ, van Keulen JW, Rantner B, Schlösser FJ, Setacci F, Ricco JB. Management of abdominal aortic aneurysms clinical practice guidelines of the European society for vascular surgery. Eur J Vasc Endovasc Surg. 2011 Jan;41(Suppl 1):S1-S58. doi: 10.1016/j.ejvs.2010.09.011 5. Patel R, Sweeting MJ, Powell JT, Greenhalgh RM. Endovascular versus open repair of abdominal aortic aneurysm in 15-years'follow-up of the UK endovascular aneurysm repair trial 1 (EVAR trial 1): a randomised controlled trial. Lancet. 2016 Nov 12;388(10058):236674. doi: 10.1016/S0140-6736(16)31135-7

6. Wanhainen A, Verzini F, Van Herzeele I, Allaire E, Bown M, Cohnert T, Dick F, van Herwaarden J, Karkos C, Koelemay M, Kölbel T, Loftus I, Mani K, Melissano G, Powell J, Szeberin Z, Esvs Guidelines Committee, de Borst GJ, Chakfe N, Debus S, Hinchliffe R, Kakkos S, Koncar I, Kolh P, Lindholt JS, de Vega M, Vermassen F, Document Reviewers, Björck M, Cheng S, Dalman R, Davidovic L, Donas K, Earnshaw J, Eckstein HH, Golledge J, Haulon S, Mastracci T, Naylor R, Ricco JB, Verhagen H. Editor's Choice European Society for Vascular Surgery (ESVS) 2019 Clinical Practice Guidelines on the Management of Abdominal Aorto-iliac Artery Aneurysms. Eur J Vasc Endovasc Surg. 2019 Jan;57(1):8-93. doi: 10.1016/j. ejvs.2018.09.020

7. Burke CR, Henke PK, Hernandez R, Rectenwald JE, Krishnamurthy V, Englesbe MJ, Kubus JJ, Escobar GA, Upchurch GR Jr, Eliason JL. A contemporary comparison of aortofemoral bypass and aortoiliac stenting in the treatment of aortoiliac occlusive disease. Ann Vasc Surg. 2010 Jan;24(1):4-13. doi: 10.1016/j. avsg.2009.09.005

8. Creager MA, Kaufman JA, Conte MS. Clinical practice. Acute limb ischemia. $N$ Engl J Med. 2012 Jun 7;366(23):2198-206. doi: 10.1056/NEJMcp1006054

\section{Адрес для корреспонденции}

04001, Словацкая Республика,

г. Кошице, ул. Ондавская, д. 8,

Восточно-Словацкий институт

сердечно-сосудистых заболеваний,

клиника сосудистой хирургии,

тел.: + 421055 789-15-10,

e-mail: i.kopolovets@gmail.com,

Кополовец Иван

\section{Сведения об авторах}

Сиготски Владимир, PhD, заместитель заведующего клиникой сосудистой хирургии по педагогической работе, сосудистый хирург, Восточно-Словацкий институт сердечно-сосудистых заболеваний, университет П.И. Шафарика, медицинский факультет, г. Кошице, Словацкая Республика. https://orcid.org/0000-0002-1446-8216

Кополовец Иван, к.м.н., сосудистый хирург, Восточно-Словацкий институт сердечно-сосудистых заболеваний, г. Кошице, Словакия, научный сотрудник ВГУЗ «Ужгородский национальный университет», г. Ужгород, Украина.
9. Huded CP, Goodney PP, Powell RJ, Nolan BW, Rzucidlo EM, Simone ST, Walsh DB, Stone DH. The impact of adjunctive iliac stenting on femoral-femoral bypass in contemporary practice. J Vasc Surg. 2012 Mar;55(3):739-45; discussion 744-5. doi: 10.1016/j. jvs.2011.10.036

10. Becquemin JP, Pillet JC, Lescalie F, Sapoval M, Goueffic Y, Lermusiaux P, Steinmetz E, Marzelle J. A randomized controlled trial of endovascular aneurysm repair versus open surgery for abdominal aortic aneurysms in low- to moderate-risk patients. $J$ Vasc Surg. 2011 May;53(5):1167-73.e1. doi: 10.1016/j. jvs.2010.10.124

11. Patel VI, Lancaster RT, Conrad MF, Lamuraglia GM, Kwolek CJ, Brewster DC, Cambria RP. Comparable mortality with open repair of complex and infrarenal aortic aneurysm. J Vasc Surg. 2011 Oct;54(4):952-59. doi: 10.1016/j.jvs.2011.03.231

12. Williams CR, Brooke BS. Effectiveness of open versus endovascular abdominal aortic aneurysm repair in population settings: A systematic review of statewide databases. Surgery. 2017 Oct;162(4):707-20. doi: 10.1016/j.surg.2017.01.014

13. Albuquerque FC Jr, Tonnessen BH, Noll RE Jr, Cires G, Kim JK, Sternbergh WC 3rd. Paradigm shifts in the treatment of abdominal aortic aneurysm: trends in 721 patients between 1996 and 2008. J Vasc Surg. 2010 Jun;51(6):1348-52; discussion 1352-53. doi: 10.1016/j. jvs.2010.01.078

14. Patel R, Powell JT, Sweeting MJ, Epstein DM, Barrett JK, Greenhalgh RM. The UK EndoVascular Aneurysm Repair (EVAR) randomised controlled trials: long-term follow-up and cost-effectiveness analysis. Health Technol Assess. 2018 Jan;22(5):1-132. doi: 10.3310/hta22050

15. Kapma MR, Dijksman LM, Reimerink JJ, de Groof AJ, Zeebregts CJ, Wisselink W, Balm R, Dijkgraaf MG, Vahl AC. Cost-effectiveness and costutility of endovascular versus open repair of ruptured abdominal aortic aneurysm in the Amsterdam Acute Aneurysm Trial. Br J Surg. 2014 Feb;101(3):208-15. doi: $10.1002 /$ bjs. 9356

\section{Address for correspondence}

04001, Slovakia,

Kosice, Ondavska Str., 8,

Eastern Slovak Institute

of Cardiovascular Diseases.

Tel. + 421055 789-15-10,

e-mail: i.kopolovets@gmail.com,

Ivan Kopolovets

\section{Information about the authors}

Sihotský Vladimir, PhD, Deputy Head of the Clinic of Vascular Surgery for Pedagogical Work, Vascular Surgeon, Eastern Slovak Institute of Cardiovascular Diseases, Pavol Jozef Safarik University, Medical Faculty, Kosice, Slovak Republic.

https://orcid.org/0000-0002-1446-8216

Kopolovets Ivan, PhD, Vascular Surgeon, Eastern Slovak Institute of Cardiovascular Diseases, Košice, Slovak Republic, Researcher of Uzhhorod National University, Uzhhorod, Ukraine.

http://orcid.org/0000-0002-2721-6114

Kubikový Maria, PhD, Vascular Surgeon, Eastern 
http://orcid.org/0000-0002-2721-6114

Кубикова Мария, PhD, сосудистый хирург, Восточно-Словацкий институт сердечно-сосудистых заболеваний, университет П.И. Шафарика, медицинский факультет, г. Кошице, Словацкая Республика. https://orcid.org/0000-0001-5628-8814

Штефанич Петер, PhD, сосудистый хирург, Восточно-Словацкий институт сердечно-сосудистых заболеваний, университет П.И. Шафарика, медицинский факультет, г. Кошице, Словацкая Республика. http://orcid.org/0000-0002-0396-3676

Катюх Владимир, $\mathrm{PhD}$, заведующий клиникой нейрохирургии, университет П.И. Шафарика, медицинский факультет, г. Кошице, Словацкая Республика. http://orcid.org/0000-0001-8044-4012

\section{Информация о статье}

Получена 8 октября 2018 г.

Принята в печать 30 мая 2019

Доступна на сайте 1 июля 2019 г.
Slovak Institute of Cardiovascular Diseases, Pavol Jozef Safarik University, Medical Faculty, Kosice, Slovak Republic.

https://orcid.org/0000-0001-5628-8814

Stefanic Peter, PhD, Vascular Surgeon, Eastern Slovak Institute of Cardiovascular Diseases, Pavol Jozef Safarik University, Medical Faculty, Kosice, Slovak Republic. http://orcid.org/0000-0002-0396-3676

Katuch Vladimir, PhD, Head of the Neurosurgery Clinic, Pavol Jozef Safarik University, Medical Faculty, Kosice, Slovak Republic.

http://orcid.org/0000-0001-8044-4012

\section{Article history}

Arrived: 08 October 2018

Accepted for publication 30 May 2019

Available online: 1 July 2019 